\title{
The Mediating Role of Organizational Citizenship Behavior and Voice Behavior in the Relationship Between Proactive Personality and Job Performance
} (Research Article)

\author{
Proaktif Kişilik ve İş Performansı Arasındaki İlişkide Örgütsel Vatandaşlık \\ Davranışı ve Seslilik Davranışının Aracı Rolü
}

Doi: 10.29023/alanyaakademik.825464

\section{Süleyman Cem BOZDOĞAN}

Öğr. Gör. Dr., Osmaniye Korkut Ata Üniversitesi, Bahçe MYO, Yönetim ve Organizasyon Bölümü

cembozdogan@osmaniye.edu.tr

Orcid No:0000-0001-7844-9973

How to cite this article: Bozdoğan, S.C. (2021). "The Mediating Role of Organizational Citizenship Behavior and Voice Behavior in the Relationship Between Proactive Personality and Job Performance". Alanya Academic Review, 5(2), pp.1069-1085.

\begin{tabular}{ll} 
ABSTRACT \\
Keywords: & $\begin{array}{l}\text { This study aims to evaluate the mediating role of organizational citizenship } \\
\text { behavior on the impact of proactive personality on job performance as well } \\
\text { as the mediating impact of employee voice behavior on the effect of } \\
\text { proactive personality on organizational citizenship behavior. The statistical } \\
\text { Proactive Personality, } \\
\text { Organizational } \\
\text { Citizenship Behavior, } \\
\text { Voice Behavior, } \\
\text { Job Performance. }\end{array} \quad \begin{array}{l}\text { analyzed by structural equation method using SPSS AMOS program. The } \\
\text { mediation functions were calculated using a process macro. As a result of } \\
\text { the study, it was discovered that proactive personality has a positive effect } \\
\text { Received: 13.11.2020 performance, with organizational citizenship actions acting as a } \\
\text { Accepted:22.04.2021 } \\
\text { mediating factor. In addition, it has been found that proactive personality } \\
\text { has a positive effect on organizational citizenship behavior and in this } \\
\text { relationship employee voice behavior has a mediating role. }\end{array}$ \\
\hline
\end{tabular}

\section{INTRODUCTION}

The idea that the market is changing every day as a result of globalization, and that there are inventions that can make life simpler, has pushed companies to keep up with this transition, to closely track technology and advances, and for their workers to reach the best quality of job performance in terms of continuity. The competitive and challenging business environment of our time requires employees to do more than fulfill their responsibilities. High performance on work that needs to be done beyond the job description - including using projected problems and opportunities - means "being proactive". For this reason, it has become necessary for organizations for employees to take individual initiatives and act proactively. Study focuses on the relationship between the proactive personality trait and job performance. Proactive personality, as described by Bateman and Crant (1993), is characterized by taking initiative and finding opportunities. Both proactive personality and organizational citizenship 
behaviour (OCB) are concerned with actions that go beyond direct task requirements; both contribute implicitly to overall organizational performance (Frese, Kring, Soose, \& Zempel, 1996). Employees with strong proactive personality are more likely to make recommendations in order to identify an obstacle or change a situation. As a result, people with a strong proactive attitude are more likely to partake in voice behavior (LePine \& Van Dyne, 1998).

Both the personality characteristics and personal performance of the personnel employed in the sector towards the organization in which they are already working are of great importance both in terms of the profitability of the organization and in terms of the unitary development of the sector. The aim of the study is to contribute health institutions, to emphasize the importance of the proactive personalities of employees for health institutions and to increase the individual business performance of employees and make a contribution to the academic community conducting research in this field. In this study several contributions are aimed to make to the literature. Firstly, it is proposed that proactive personality would enhance Employee performance and OCB will mediate this relationship. Secondly, it is proposed that proactive personality would enhance OCB and voice behavior will mediate this relationship.

\section{LITERATURE REVIEW}

Proactive personality is a trait that constantly engages the individual in order to achieve the desired change (Kale, 2019: 145). According to Fuller and Marler (2009: 331) The dispositional proclivity of an individual to impose their environment or circumstance by constructive behaviors is referred to as proactive personality. The essence of the proactive personality is that people differ in their capacity to control and monitor their environment, resulting in discrepancies in their tendency to practice change-oriented behavior.

Proactive personality relates to individuals ' ability to assume active tasks, such as promoting improvement and shaping their climate, individuals with prototypical positive personalities "identify and respond upon incentives, display commitment, pursue action, and persevere before substantive progress happens" (Crant, 2000: 439). Individuals with pro-active personalities are largely free from societal strain (Bateman \& Crant, 1993), tend to have high aspirations and use all the resources possible to achieve those targets (Crant, 1996). Proactive personality combines the motivation and dedication to improve that is central to selfdevelopment models (Antonacopoulou, 2000). People with proactive personalities are expected to recognise and respond on incentives, display personal responsibility and seek meaningful progress (Crant, 1995). Non-proactive or inactive individuals do not constantly monitor the atmosphere for ways to improve their environments, nor do they pursue steps as changes arise, they are more inclined to react rather than adopt environmental change. Proactive conduct is thus considered a healthy trait characterized by a tendency to "take personal responsibility for a wide range of activities and situations." (Seibert, Kraimer, \& Crant, 2001: 847).

OCB can be defined as a conduct that goes beyond formal labor criteria and benefits the enterprise (Spector, 2006). Initially, OCB was conceived and adopted as an entity-level concept that refers to employee behaviour that goes far beyond service, is voluntary and not explicitly adopted by the company's formal incentive system and thus contributes to corporate success (Organ, 1988; Smith, Organ \& Close, 1983). Commonly used in scholarly literature, OCB conceptualization considers it to consist of five dimensions: altruism, generalized 
compliance, sportsmanship, courtesy and civic virtue (Podsakoff et al., 2000). Altruism is assisting peers or superiors, while generalized conformity is employee conscience that exceeds enforceable job expectations, sportsmanship is work patience, civic virtue is the positive engagement and interest of workers in business relations tasks such as holding workshops, listening to correspondence and discussing operational problems. In recent years, current theoretical and empirical research has centered on a deeper understanding of the basic motivations of voice behavior (Morrison, 2011: 373).

Linn Van Dyne and LePine (1998: 109) describe voice behavior as promotive activity that stresses transmission of positive criticism directed at changing rather than simply attacking. Voice behavior among workers is an example of constructive behavior (Crant, 2000; Grant \& Ashford, 2008; Morrison, 2011) that involves speaking up with comprehensive suggestions and thoughts about work-related topics (Van Dyne et al., 2003).

Tangirala and Ramanujam (2008: 1189) describe voice behavior as employees' communication of demanding yet positive views, thoughts, or work-related ideas. Voice behavior is a speech action that arises when a person has an idea or viewpoint to convey in order to change a situation (Wong, Laschinger, \& Cummings, 2010). Voice behavior in organizational success may play a prominent role through promoting progress and creativity, particularly in difficult times, when innovative ideas encourage quality improvement. The message expressed by voice may be regarding a need to change (Van Dyne \& LePine, 1998), an operational or work-related concern (Milliken et al., 2003), an unequal or wrongdoing condition (Pinder \& Harlos, 2001), a significant strategic question (Dutton \& Ashford, 1993), or a perspective that varies from others' opinions (Premeaux \& Bedeian, 2003). Voice behavior refers to work communication or organizationally appropriate feedback that suggests either an incentive to do things better or a need to cancel or change current practices. Voice definition is implicit in the awareness that such behavior always poses a danger, as even a comparatively positive proposal poses a threat to the status quo (Liu, Zhu, \& Yang, 2010).

Job performance is described as the total predicted profit to the organization from a person's various behaviour episodes over a given time span. This description is a somewhat updated variant of the concept of success in a previous publication linked to a hypothesis of human discrepancies in role and contextual success (Motowildo, Borman, \& Schmit, 1997). Job performance is considered to be the degree a person helps organization to accomplish its aim. Many businessmen consider job performance as the best place to obtain details on how good workers do their work. Job performance is a distinct institution's overall predicted benefit worker's behavioral occurrence over a given duration (De Boer, Van Hooft, \& Bakker, 2015: 5). This would be beneficial for the wide variety of approaches and techniques that may be found in the corporate sector that are essential to enhancing individual efficiency in job organization. Individual job performance can be described as what people do or acts that play a role and lead to an organization's objectives (Sonnentag \& Starzyk, 2015).

The mediating effect of OCB on the effect of proactive behavior on job performance, and mediating effect of voice behavior in the effect of proactive behavior on Ocb was determined. There have been no other studies highlighting these mediating effects. The aim of this study is to fill the gap in the literature. 


\section{RELATIONSHIP BETWEEN VARIABLES}

\subsection{Proactive personality and organizational citizenship behavior}

Proactivity inside an employee contributes to a preference for greater results environment and a number of positive results are related. Individuals deliberately working to change their workforce would be more inclined to participate in OCB-like activities as, by their very definition, cultivate the organizational environment and strengthen the workforce for all workers and organizations (Liguori, McLarty, \& Muldoon, 2013: 729). Highly conscientious employees are most inclined to try to better the organisation that hires them by undertaking activities such as staying above average performance rates, staying vigilant while they are unable to function and observing implicit behavioral guidelines that help preserve order. Proactive personality and OCB have a view of interpersonal behaviors that go beyond direct roles; both actively add to the broader contribute to organization (Frese, Kring, Soose, \& Zempel, 1996). As OCB performance contributes to high job achievement, it would make sense to want proactive individuals to perform OCB as a means of achievement (Fuller Jr \& Marler, 2009; Podsakoff, Whiting \& Blume, 2009; Jawahar \& Liu, 2016). In the light of these arguments will test the following hypothesis:

$\mathrm{H}_{1}$. Proactive personality and organizational citizenship behavior are positively correlated.

\subsection{Proactive personality and job performance}

Proactive personality is also associated with a personal commitment for redefining performance, or the degree to which one feels personally responsible for results redefining. (McCormick et al., 2019). Proactive personality has been found to have a positive effect on an individual's interest in workplace change programs and to successfully enhance additional employee work attitudes (Liguori et al.,2013). A significant number of researchers have reported attitudes that represent the proactive actions of employees i.e. (Ashford \& Cummings, 1985; Dutton, Ashford, Lawrence, \& Miner-Rubino, 2002; LePine \& Van Dyne, 1998; Morrison \& Phelps, 1999; Staw \& Boettger, 1990). Such work has contributed to a vast yet somewhat dizzying variety of constructs that explain proactive employee's behaviour. Crant (2000) has provided an excellent review of many of these streams of research. Proactive personality is seen as a propensity to behave to control one's surroundings (Bateman \& Crant, 1993). We assume that individuals with a proactive attitude exploit their surroundings in accordance with the interactionist perspective to encourage higher standards of success (Baba, Tourigny, Wang, \& Liu, 2009). The proactive personality tends to be related to other beneficial habits such as job performance, team productivity and leadership (Crant, 2000). In the light of these arguments will test the following hypothesis:

$\mathrm{H}_{2}$. Proactive personality and job performance are positively correlated.

\subsection{Organizational citizenship behavior and job performance}

For various factors, OCB was supposed to contribute favorably to an employee's job performance. A contextual analysis will explain OCB's association with organizational success (Sun, Aryee, \& Law, 2007) and job performance (Chow, 2009). According to this viewpoint, OCB workers can form high-quality peer relationships by assisting an organization's emotional needs. They will also help workers understand what they need to complete their assignments. 
High OCB engagement implies close links and contributes to better work results. Relationship approach is particularly useful as an interpretation of the relationship between OCB and job performance, as OCB activities can foster interpersonal relationships, mitigate conflict and tension, reduce time costs, and increase efficiency and quality (Podsakoff et al., 2009; Smith et al., 1983). Previous studies find clear and indirect proof of a favorable association between OCB and job performance (Brown, Kamin, \& Lord, 2002; Chow, 2009; Diefendorff; Piercy, Cravens, Lane, \& Vorhies, 2006; Lee, Mitchell, Sablynski, Burton, \& Holtom, 2004; Wang, Law, Hackett, Wang, \& Chen, 2005; Basu, Pradhan \&Tewari, 2017; Supriyadi, Sanusi \& Manan, 2017). In the light of these arguments will test the following hypothesis:

$\mathrm{H}_{3}$. Organizational citizenship behavior and job performance are positively correlated.

\subsection{Proactive personality and voice behavior}

Proactive workers appear to aggressively pursue approaches to corporate challenges, which might not be included in their structured roles. Employees that are proactive are very valuable in the workplace (Wang et al., 2017). They also initiate useful political discourse to provide relevant knowledge to other members of the organization (Thompson, 2005). Therefore, proactive employees should communicate their ideas with the good of their personnel management to facilitate constructive improvements. Fuller and Marler (2009) reported that proactive personality was related to voice behavior in a positive and significant way. Besides this, Xie et al. (2014) suggested that proactive personality is positively related to the voice behavior of Chinese workers. Moreover, Kanten and Ülker (2012) discovered a significant relationship between these two variables; they believe that proactive personality is one of the most important factors affecting voice behaviour. In the light of these arguments will test the following hypothesis:

$\mathrm{H}_{4}$. Proactive personality and voice behavior are positively correlated.

\subsection{Voice behavior and organizational citizenship behavior}

Throughout recent years, more focus has been given to voice behavior than any other particular aspect of the OCB system. As mentioned above, a significant philosophical and scientific addition to voice behavior literature emerged in Maynes and Podsakoff (2014) research. They stated that the voice behavior could take multiple forms, not only as negative reinforcement or "challenge to what is" but also in positive, protective or even disruptive veins. OCB related to affiliations contribute to the organisation by strengthening the social and psychological functioning of the work context (Organ, 1997; Rotundo \& Sackett, 2002), correlate with voice behavior (LePine \& Van Dyne, 1998). It should be noted that some scholars have indicated that, since voice behavior can be fairly subjective and affect the consistency of the psychological and social meaning, it can be used as a form of OCB or its near relative (Podsakoff et al., 2009). In the light of these arguments will test the following hypothesis:

$\mathrm{H}_{5}$. Voice behavior and organizational citizenship behavior are positively correlated.

The above conceptual framework and empirical studies reveal the direct relationships between these variables. Based on the fact that there are direct relationships between the variables, mediation hypotheses of OCB and voice behavior were created below. 
$\mathrm{H}_{6}$ : Organizational citizenship behavior has a mediating role in the effect of proactive personality on job performance.

$\mathrm{H}_{7}$ : In the influence of proactive personality on organizational citizenship behavior, voice behavior has a mediating role.

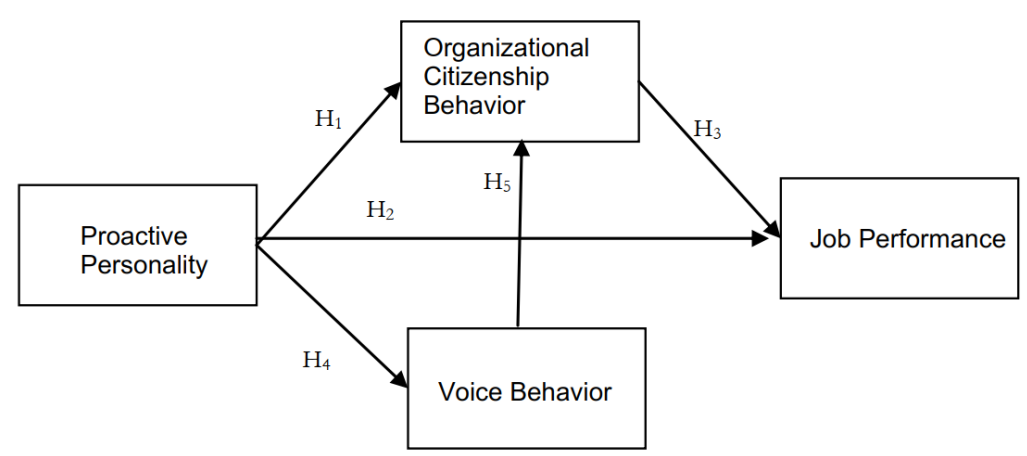

Figure 1. Research Model

\section{METHOD AND SAMPLE}

\subsection{The universe and sample of research}

The data used in the analysis in the research was obtained through the survey method. In the survey expressions were arranged using the Likert scale. Proactive personality, OCB, voice behavior and job performance scale exist in the questionnaire. In addition to statements regarding proactive personality, OCB, voice behavior and job performance, participants' demographic questions also included. Private hospital personnel constitute the universe of the research. The sample is the personnel in the Private hospitals in Osmaniye district, selected by easy sampling method. Doctors in the emergency service couldn't participate our research due to the high load caused by Corono Virus Epidemic. 500 survey forms were planned to be filled out at all private hospitals in the district. In order to determine whether the sample size $(n=447)$ in the study represents the universe, the sample calculation formula developed by Barlett, Körtlik and Higgins (2001) used (Gürbüz and Şahin, 2017: 128-130).

$\mathrm{N}$ : Size of the Universe

$$
\begin{aligned}
& \mathrm{n}=\left[\mathrm{n}_{0} /\left(1+\mathrm{n}_{0} / \mathrm{N}\right)\right] \\
& \mathrm{n}_{0}=\left[\left(\mathrm{t}^{2} \mathrm{xs}^{2}\right) / \mathrm{d}^{2}\right]
\end{aligned}
$$

$\mathrm{n}$ : Size of the Sample

t: Value for $95 \%$ confidence is 1.96.

$\mathrm{s}$ : Predicted standard deviation for the universe

$\mathrm{d}$ : Acceptable deviation tolerance

$$
\begin{aligned}
& \mathrm{n}_{0}=\left[\left(1.96^{2} \mathrm{x} 0.5^{2}\right) / 0.05^{2}\right]=384.16 \\
& \mathrm{n}=[384.16 /(1+384.16 / 700)]=248.03
\end{aligned}
$$


As a result of the calculation, it was found that the universe consisting of 700 people with a 95\% confidence level and 0.05 sample error could represent a sample of 248 people. Accordingly, it is seen that the research sample consisting of 447 participants is sufficient.

Of the surveys conducted, 50 polls were unanswered, while 3 polls were unfinished. The sample has then been determined as 447.56 of the staff are Doctors, 197 are allied health personnel (Nurse, paramedic, analyst etc.), 100 are administrative personnel, 67 are technical personnel and 27 are cleaning personnel. 226 of the staff are female while 221 are male. 110 of the employees are aged 20-25, 104 are aged 26-30, 114 are aged 31-40 and 119 are in the age range of 41 and over. In terms of work experience, 200 of the employees have 1-3 years, 180 have 4-9 years and 67 have 10 years or more of work experience.

\subsection{Data collection tools}

Proactive personality was analyzed by the ten-item scale (Seibert et al., 1999). A shortened proactivity scale was used to assess participants ' proactivity levels. The adaptation of the scale to Turkish was carried out by Akın, Abaci, Kaya and Arıc1 (2011). The shortened proactivity scale of 10 items gives likert-type measurements between 1 and 7 . As total scores from the scale increase, the level of proactivity increases. The proactive personality scale's Cronbach Alpha reliability coefficient was 0.90 .

Voice behavior: The Van Dyne and Le Pine (1998) six-item scale was used. The adaptation of voice behavior scale to Turkish was made by Arslan and Yener (2006). Voice behavior scale has a single-factor structure. Voice behavior scale's Cronbach Alpha reliability coefficient was 0.93 .

OCB: Kumar and Shah (2015) developed a 15-item and five-factor scale. The short form of the scale was adopted by Podsakoff, MacKenzie, Moorman, and Fetter (1990). The Ocb scale's Cronbach Alpha reliability coefficient was 0.844 .

Job performance: A 4-item employee performance scale was used first by Kirkman and Rosen (1999), and then by Sigler and Pearson (2000). It was adapted into Turkish by Çöl (2008). The job performance scale's Cronbach Alpha reliability coefficient was 0.90 .

\subsection{Findings}

Research data were analyzed with SPSS and AMOS package programs. Confirmatory factor analyzes are given in Table 1 .

Table 1. Goodness of Fit Values

\begin{tabular}{|c|c|c|c|c|c|c|c|c|}
\hline \multirow{2}{*}{$\begin{array}{l}\text { Goodness } \\
\text { of Fit Values }\end{array}$} & $\chi^{2}$ & df & CMIN/DF & GFI & $\begin{array}{c}\text { AGF } \\
\text { I }\end{array}$ & CFI & TLI & RMSEA \\
\hline & & & $\leq 5$ & $\geq 0.85$ & $\geq 0.85$ & $\geq 0.90$ & $\geq 0.90$ & $\leq 0.08$ \\
\hline Proactive Personality & 101.322 & 34 & 2.980 & .958 & .932 & .973 & .964 & .067 \\
\hline $\begin{array}{c}\text { Organizational Citizenship } \\
\text { Behavior }\end{array}$ & 274.495 & 79 & 3.475 & .923 & .884 & .963 & .951 & .074 \\
\hline Job Performance & 1.237 & 1 & 1.237 & .999 & .986 & .999 & .999 & .023 \\
\hline
\end{tabular}




\begin{tabular}{|l|r|r|r|r|r|r|r|r|}
\hline Voice Behavior & 33.908 & 9 & 3.768 & .974 & .940 & .990 & .983 & 0.79 \\
\hline
\end{tabular}

As a result of the CFA, it is seen that the scales provide goodness of fit values and show good fit.

Analyses on the data obtained from the research were performed through SPSS 24, Process Macro and SPSS AMOS packages. In this context, in the first stage, standard deviations, the means and correlations of the obtained data related to proactive personality, OCB, job performance and voice behavior levels of participants were investigated.

Table 2. Descriptive Statistics and Correlation Coefficients

\begin{tabular}{|c|c|c|c|c|c|c|c|c|}
\hline & Mean & Sd. & Skewness & Kurtosis & 1 & 2 & 3 & 4 \\
\hline 1. PP & 5.14 & .42 & -.200 & -.238 & $(.90)$ & & & \\
\hline 2. OCB & 4.67 & .89 & -.595 & .627 & $.392^{* * *}$ & $(.85)$ & & \\
\hline 3. JP & 5.10 & 1.19 & -.801 & .756 & $.576^{* *}$ & $.392^{* *}$ & $(.91)$ & \\
\hline 3. VOICE & 4.71 & 1.47 & -.74 & -.029 & $.409^{* *}$ & $.634^{* *}$ & $.438^{* *}$ & $(.94)$ \\
\hline
\end{tabular}

When the descriptive statistics of the research variables are evaluated, it is observed that the participants proactive personality, OCB, job performance and voice behavior levels were moderate. In addition, when Table 2 is examined, positive and meaningful relationships between variables are observed. In the second phase, a structural model for the research model was established and goodness of fit values were tested with the SPSS AMOS program. Structural equation model is given in Figure 2, goodness of fit values are given in Table 3 and regression weights are given in Table 4. 




Figure 2. Structural Equation Model

Table 3. Structural Model Goodness of Fit Values

\begin{tabular}{|l|c|c|c|c|c|c|}
\hline Goodness of Fit Values & $\chi \mathbf{2}$ & df & $\begin{array}{c}\text { CMIN/DF } \\
\mathbf{5}\end{array}$ & $\begin{array}{l}\text { CFI } \\
\geq \mathbf{0 . 9 0}\end{array}$ & $\begin{array}{c}\text { TLI } \\
\geq \mathbf{0 . 9 0}\end{array}$ & $\begin{array}{c}\text { RMSEA } \\
\leq \mathbf{0 . 0 8}\end{array}$ \\
\hline Structural Modal & 1593.842 & 546 & 2.919 & 0.90 & 0.91 & 0.066 \\
\hline
\end{tabular}

As can be seen in Table 3, the structural equation model established to test the research hypotheses provides acceptable goodness of fit values.

Table 4. Structural Model Regression Weights

\begin{tabular}{|c|c|c|c|c|c|c|}
\hline \multicolumn{3}{|c|}{ Tested Path } & Estimate & Std.E. & CR & P \\
\hline PP & $--->$ & OCB & .292 & .110 & 2.650 & .008 \\
\hline PP & $--->$ & JP & 1.386 & .230 & 6.017 & $* * *$ \\
\hline OCB & $--->$ & JP & .196 & .048 & 4.118 & $* * *$ \\
\hline PP & $--->$ & VOICE & 1.309 & .232 & 5.635 & $* * *$ \\
\hline
\end{tabular}




\begin{tabular}{|l|l|l|l|l|l|l|} 
VOICE & $--->$ & OCB & .451 & .040 & 11.409 & $* * *$ \\
\hline
\end{tabular}

In the light of these results, the hypothesis $\mathrm{H}_{1}, \mathrm{H}_{2}, \mathrm{H}_{3}, \mathrm{H}_{4}$ and $\mathrm{H}_{5}$ was supported. In order to test the $\mathrm{H}_{6}$ and $\mathrm{H}_{7}$ hypothesis mediation analysis was performed using the Hayes Process macro Spss addon.

\subsection{Mediation analysis}

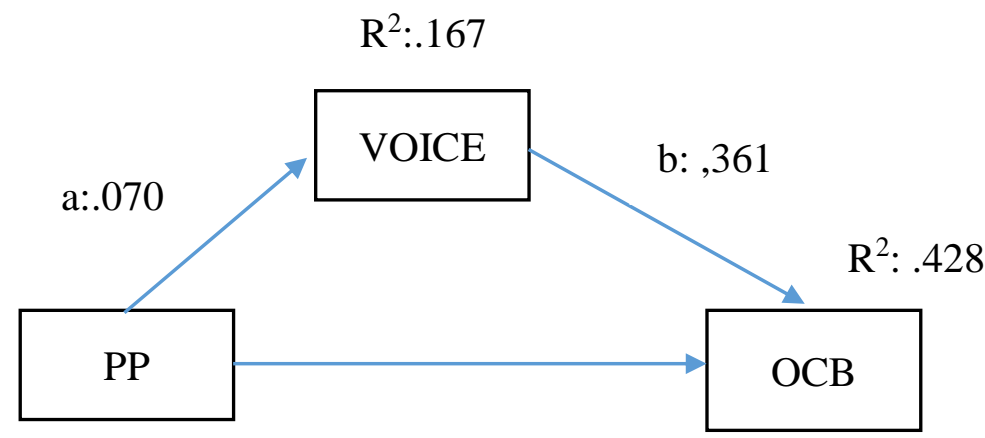

Figure 3. Voice behaviour plays a mediating role in the relationship between proactive personality and OCB $(\mathrm{N}=447)$

Direct Impact (c'): .143

Indirect Impact Value (a.b) $=.2418, \% 95$ CI $[.171, .319]$

$\mathrm{R}$ square values show the variance described

Note: Unstandardized beta coefficients are reported.

To see whether voice behavior plays a mediating role in the effect of proactive personality on organizational citizenship behavior, Bootstrap-based regression method used. Process macro is used to perform the analysis. The analysis chose 5000 resampling options with the bootstrap methodology. Regression analysis results for this purpose are given in Figure 3 the confidence intervals obtained using the bootstrap approach were used to determine if the voice has an indirect impact on OCB. Accordingly, it has been determined that the indirect effect of proactive personality on business performance is meaningful, therefore, the perception of organizational citizenship mediates the relationship between proactive personality and job performance $(b=.241,95 \%$ CI $[.1714, .3193)$. The percentage procedure yields lower and upper confidence interval values that do not contain a 0 (zero) value. In the light of these results, the $\mathrm{H}^{6}$ hypothesis of the research was supported. 


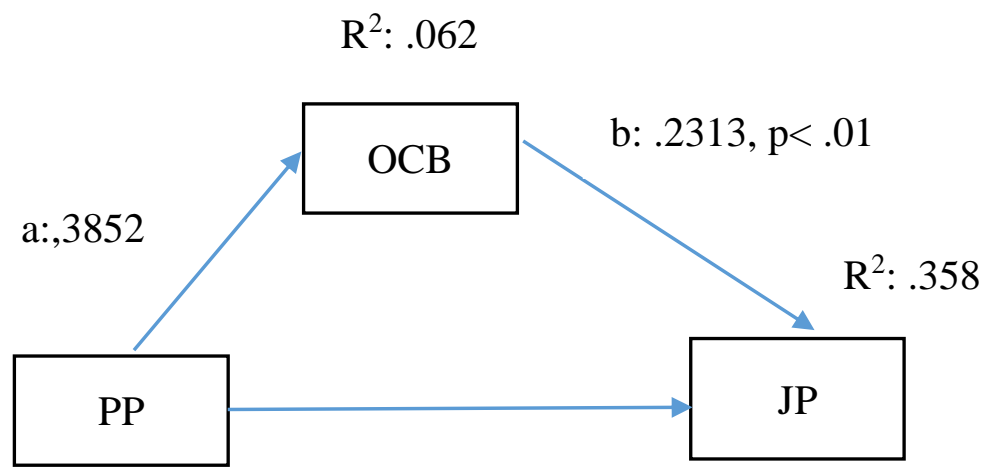

Figure 4: OCB plays a mediating role in the relationship between proactive personality and job performance. $(\mathrm{N}=447)$

Direct Impact $\left(\mathrm{c}^{\prime}\right)=.6743, \mathrm{p}<.01$

Indirect Impact $(\mathrm{a} . \mathrm{b})=.891, \% 95 \mathrm{CI}[.039, .150]$

$\mathrm{R}$ square values show the variance described

Note: Unstandardized beta coefficients are reported.

A Bootstrap-based regression analysis was performed to assess whether the sense of OCB plays a mediation role in the impact of proactive personality on job performance. Analyses is carried out using Hayes' (2018) Process Macro. The results of the regression analysis for this context are seen in Figure 4. Based on the confidence intervals gained with the Bootstrap methodology, whether the proactive personality has an indirect impact on market success was determined. Accordingly, it has been determined that the indirect effect of proactive personality on job performance is meaningful, therefore, the perception of OCB mediates the interaction between proactive personality and job performance $(b=.089,95 \%$ CI $[.0392$, .1505). The percentage procedure yields lower and upper confidence interval values that do not contain a 0 (zero) value. In the light of these results, the $\mathrm{H}^{7}$ hypothesis of the research was supported.

\section{RESULTS}

Data collected through the survey were analyzed in order to define mediation the role of OCB and voice behavior in the relationship between proactive personality and job performance. This research was conducted in private hospitals. As a result of the analysis, it was determined that proactive personality effects OCB positively and significantly. This result is consistent with the study findings aimed at assessing the effects of proactive personality on OCB (Frese et al., 1996; Fuller Jr \& Marler, 2009; Liguori et al., 2013; Podsakoff et al., 2009; Jawahar \& Liu, 2016). This finding suggests that proactive behavior strenghtens OCB. Highly proactive employees are most inclined to try to better the organisation that hires them by conducting activities such as staying above average performance rates, staying cautious while they are unable to function, and observing implicit behavioral guidelines that help preserve order. Besides strengthening the organisation, proactive individuals would continue to conduct OCBs focused on wanting to develop their careers. Proactive people set a strong bar for reaching large degrees of achievement (Fuller Jr \& Marler, 2009). 
Proactive personality has a positive impact on job performance, which is significantly compatible with the outcome of (Baba et al., 2009; Bateman \& Crant, 1993; Crant, 2000). According to Crant (1995), citizens are highly proactive show better performance than more passive individuals because they engage behaviors that allow significant work-related contributions. Investigators ought to link proactive personality to maybe the most popular and significant work performance measure — formal workplace performance evaluation.

OCB positively effects job Performance significantly result is consistent with the result of (Chow, 2009; Diefendorff et al., 2002; Lee et al., 2004; Piercy et al., 2006; Wang et al., 2005; Basu, Pradhan \&Tewari, 2017; Supriyadi, Sanusi \& Manan, 2017; McCormick et al., 2019). The results support OCB's claim of earlier research to increase the capacity of colleagues and administrators to conduct their roles by more effective preparation, organizing and problem solving (MacKenzie, Podsakoff, \& Fetter, 1991). Organizations that encourage good citizenship behaviors are more desired by employers and will recruit, maintain the best employees (George \& Bettenhausen, 1990).

Proactive personality positively effects voice behavior significantly result is consistent with the findings of (Fuller Jr \& Marler, 2009; Kanten \& Ulker, 2012; Thompson, 2005; Wang et al., 2017). Network-building, communicative socialization, job effort and positive work habits such as accepting responsibilities, problem prevention and voice behavior, is forecasted by proactive personality (Parker, Bindl, \& Strauss, 2010; Parker \& Collins, 2010: 10). Voice behavior is an effective and positive conduct that seeks to enhance rather than condemn. A proactive individual 's personal temperament will definitely contribute favorably to the voice and precede the voice intervention (Ristig, 2008: 142).

Voice behavior effects OCB positively and significantly result is consistent with the findings of (LePine \& Van Dyne, 1998; Organ, 1997; Podsakoff et. al., 2009; Rotundo \& Sackett, 2002). More recently, OCB literature identified voice behavior as a type of extra-role activity that occurs when employees communicate positive improvement ideas constructively (LePine \& Van Dyne, 2001; Van Dyne, Cummings, \& Parks, 1995). Voice behavior is one specific type of proactive employee behavior.

OCB's mediating role in the impact of proactive personality on job performance was described as a consequence of the research carried out. This finding show that OCB has an enhancive role in the impact of proactive personality and Job performance and also voice behavior has a mediating role in the impact of proactive personality on OCB.

Both observations should be analyzed within the chosen study, the selected survey tool, crosssectional analysis limitations. The most significant contribution of this research to the literature is the manifestation that OCB mediates the effect of proactive personality on job performance, and that voice behavior mediates the impact of proactive personality on OCB. In this regard, this study will contribute to the evaluation of the literature. Future studies should add various variables like leader member exchange, organizational commitment and measure with a time interval.

\section{REFERENCES}

ANTONACOPOULOU, E. P. (2000). "Employee development through self-development in three retail banks". Personnel Review, 29(4): 491-508. 
ASHFORD, S. J., \& CUMMINGS, L. L. (1985). "Proactive feedback seeking: The instrumental use of the information environment". Journal of occupational psychology, 58(1): 67-79.

BABA, V. V., TOURIGNY, L., WANG, X., \& LIU, W. (2009). "Proactive personality and work performance in China: The moderating effects of emotional exhaustion and perceived safety climate". Canadian Journal of Administrative Sciences/Revue Canadienne des Sciences de l'Administration, 26(1): 23-37.

BARTLETT, J.E.; J. W. KORTLIK; C. C. HIGGINS (2001) "Organizational Research: Determining Appropriate Sample Size In Survey Research” Information Tecnology, Learning and Performance Journal, 19(1): 43-50

BASU, E., PRADHAN, R. K., \& TEWARI, H. R. (2017). "Impact of Organizational Citizenship Behavior on Job Performance in Indian Healthcare Industries: The Mediating Role of Social Capital". International Journal of Productivity and Performance Management, 66(6): 780-796

BATEMAN, T. S., \& CRANT, J. M. (1993). "The proactive component of organizational behavior: A measure and correlates". Journal of organizational behavior, 14(2): 103118.

CHOW, I. H.-S. (2009). "The relationship between social capital, organizational citizenship behavior, and performance outcomes: an empirical study from China". SAM Advanced Management Journal, 74(3): 44.

CRANT, J. M. (1995). “The proactive personality scale and objective job performance among real estate agents". Journal of applied psychology, 80(4): 532.

CRANT, J. M. (1996). "The proactive personality scale as a predictor of entrepreneurial intentions". Journal of small business management, 34: 42-49.

CRANT, J. M. (2000). "Proactive behavior in organizations". Journal of management, 26(3): 435-462.

DE BOER, B. J., VAN HOOFT, E. A., \& BAKKER, A. B. (2015). "Self-control at work: its relationship with contextual performance". Journal of managerial psychology, 30(4): 406-421

DIEFENDORFF, J. M., BROWN, D. J., KAMIN, A. M., \& LORD, R. G. (2002). "Examining the roles of job involvement and work centrality in predicting organizational citizenship behaviors and job performance". Journal of organizational behavior, 23(1): 93-108.

DUTTON, J. E., ASHFORD, S. J., LAWRENCE, K. A., \& MINER-RUBINO, K. (2002). "Red light, green light: Making sense of the organizational context for issue selling". Organization Science, 13(4): 355-369.

FRESE, M., KRING, W., SOOSE, A., \& ZEMPEL, J. (1996). "Personal initiative at work: Differences between East and West Germany". Academy of Management journal, 39(1): 37-63. 
FULLER Jr, B., \& MARLER, L. E. (2009). "Change driven by nature: A meta-analytic review of the proactive personality literatüre". Journal of vocational behavior, 75(3): 329-345.

GEORGE, J. M., \& BETTENHAUSEN, K. (1990). "Understanding prosocial behavior, sales performance, and turnover: A group-level analysis in a service context". Journal of applied psychology, 75(6): 698-709.

GRANT, A. M., \& ASHFORD, S. J. (2008). "The dynamics of proactivity at work". Research in Organizational Behavior, 28: 3-34

GÜRBÜZ, S., ŞAHİN F. (2017) Sosyal Bilimlerde Araştırma Yöntemleri, 4.Bs Ankara, Seçkin Yayıncılık.

JAWAHAR, I. M., \& LIU, Y. (2016). "Proactive personality and citizenship performance". Career Development International, 21(4): 378-401

KALE, E. (2015). "The impact of proactive personality and locus of control on career satisfaction and inno-vative work behavior". Journal of Tourism Theory and Research, 5(2): $144-154$

KANTEN, P., \& ULKER, F. E. (2012). "A relational approach among perceived organizational support, proactive personality and voice behaviour". Procedia-Social and Behavioral Sciences, 62: 1016-1022.

KUMAR, M. M., \& SHAH, S. A. (2015). "Psychometric properties of Podsakoff's organizational citizenship behaviour scale in the Asian context". The International Journal of Indian Psychology, 3(1): 51-60.

LEE, T. W., MiTCHELl, T. R., SABlynSKI, C. J., BURTON, J. P., \& HOLTOM, B. C. (2004). "The effects of job embeddedness on organizational citizenship, job performance, volitional absences, and voluntary turnover". Academy of management journal, 47(5): 711-722.

LEPINE, J. A., \& VAN DYNE, L. (1998). "Predicting voice behavior in work groups". Journal of applied psychology, 83(6): 853-868.

LEPINE, J. A., \& VAN DYNE, L. (2001). "Voice and cooperative behavior as contrasting forms of contextual performance: evidence of differential relationships with big five personality characteristics and cognitive ability". Journal of applied psychology, 86(2): 326-336.

LIGUORI, E. W., MCLARTY, B. D., \& MULDOON, J. (2013). "The moderating effect of perceived job characteristics on the proactive personality-organizational citizenship behavior relationship". Leadership \& Organization Development Journal, 34(8): 724740

LIU, W., ZHU, R., \& YANG, Y. (2010). "I warn you because I like you: Voice behavior, employee identifications, and transformational leadership". The leadership quarterly, 21(1): 189-202.

MACKENZIE, S. B., PODSAKOFF, P. M., \& FETTER, R. (1991). "Organizational citizenship behavior and objective productivity as determinants of managerial 
evaluations of salespersons' performance". Organizational behavior and human decision processes, 50(1): 123-150.

MAYNES, T. D., \& PODSAKOFF, P. M. (2014). "Speaking more broadly: An examination of the nature, antecedents, and consequences of an expanded set of employee voice behaviors". Journal of applied psychology, 99(1): 87-112.

MCCORMICK, B.W., GUAY, R.P., COLBERT, A.E. and STEWART, G.L. (2019), "Proactive personality and proactive behaviour: perspectives on person-situation interactions", Journal of Occupational and Organizational Psychology, 92(1): 30-51.

MORRISON, E. W. (2011). "Employee voice behavior: Integration and directions for future research". Academy of Management annals, 5(1): 373-412.

MORRISON, E. W., \& PHELPS, C. C. (1999). "Taking charge at work: Extrarole efforts to initiate workplace change". Academy of management Journal, 42(4): 403-419.

MOTOWILDO, S. J., BORMAN, W. C., \& SCHMIT, M. J. (1997). "A theory of individual differences in task and contextual performance”. Human performance, 10(2): 71-83.

ORGAN, D. W. (1988). Organizational citizenship behavior: The good soldier syndrome: Lexington Books/DC Heath and Com.

ORGAN, D. W. (1997). “Organizational citizenship behavior: It's construct clean-up time”. Human performance, 10(2): 85-97.

PARKER, S. K., BINDL, U. K., \& STRAUSS, K. (2010). “Making things happen: A model of proactive motivation". Journal of management, 36(4): 827-856.

PARKER, S. K., \& COLLINS, C. G. (2010). "Taking stock: Integrating and differentiating multiple proactive behaviors". Journal of management, 36(3): 633-662.

PIERCY, N. F., CRAVENS, D. W., LANE, N., \& VORHIES, D. W. (2006). "Driving organizational citizenship behaviors and salesperson in-role behavior performance: The role of management control and perceived organizational support". Journal of the Academy of Marketing Science, 34(2): 244-262.

PODSAKOFF, N. P., WHITING, S. W., PODSAKOFF, P. M., \& BLUME, B. D. (2009). "Individual-and organizational-level consequences of organizational citizenship behaviors: A meta-analysis”. Journal of applied psychology, 94(1): 122-141.

PODSAKOFF, P. M., \& MACKENZIE, S. B. (1997). "Impact of organizational citizenship behavior on organizational performance: A review and suggestion for future research". Human performance, 10(2): 133-151.

PODSAKOFF, P. M., MACKENZIE, S. B., MOORMAN, R. H., \& FETTER, R. (1990). "Transformational leader behaviors and their effects on followers' trust in leader, satisfaction, and organizational citizenship behaviors. The leadership quarterly, 1(2): 107-142.

RISTIG, K. (2008). "An empirical investigation of the relationship between trust, voice, and proactive personality". European Journal of Economics, Finance and Administrative Sciences, 14(14): 141-148. 
ROTUNDO, M., \& SACKETT, P. R. (2002). "The relative importance of task, citizenship, and counterproductive performance to global ratings of job performance: A policycapturing approach". Journal of applied psychology, 87(1): 66-80.

SEIBERT, S. E., KRAIMER, M. L., \& CRANT, J. M. (2001). "What do proactive people do? A longitudinal model linking proactive personality and career success". Personnel psychology, 54(4): 845-874.

SMITH, C., ORGAN, D. W., \& NEAR, J. P. (1983). “Organizational citizenship behavior: Its nature and antecedents”. Journal of applied psychology, 68(4): 653-663.

SONNENTAG, S., \& STARZYK, A. (2015). "Perceived prosocial impact, perceived situational constraints, and proactive work behavior: Looking at two distinct affective pathways". Journal of Organizational Behavior, 36(6): 806-824.

SPECTOR, P. E. (2006). Industrial and organizational psychology: Research and practice: John Wiley \& Sons Inc.

STAW, B. M., \& BOETTGER, R. D. (1990). "Task revision: A neglected form of work performance". Academy of Management Journal, 33(3): 534-559.

SUPRIYYAİ, A, SANUSI, A, MANAN, A. (2017). "A Study on the Performance of Manufacturing Employees: Organizational Culture, Compensation, Organizational Commitment, and Organizational Citizenship Behavior". European Journal of Business and Management, 9(6): 32-43

SUN, L.-Y., ARYEE, S., \& LAW, K. S. (2007). "High-performance human resource practices, citizenship behavior, and organizational performance: A relational perspective". Academy of management Journal, 50(3): 558-577.

TANGIRALA, S., \& RAMANUJAM, R. (2008). "Exploring nonlinearity in employee voice: The effects of personal control and organizational identification". Academy of Management Journal, 51(6): 1189-1203.

THOMPSON, J. A. (2005). "Proactive personality and job performance: a social capital perspective". Journal of applied psychology, 90(5): 1011-1017.

VAN DYNE, L., CUMMINGS, L., \& PARKS, J. M. (1995). Extra role behaviors: In pursuit of construct and definitional clarity. LL Curamings, BM Staw, eds. Research in organizational behavior, 17, 215-285.

VAN DYNE, L., \& LEPINE, J. A. (1998). "Helping and voice extra-role behaviors: Evidence of construct and predictive validity". Academy of Management journal, 41(1): 108119.

VAN DYNE, L., ANG, S., \& BOTERO, I. C. (2003). "Conceptualizing employee silence and employee voice as multidimensional constructs". Journal of Management Studies, 40: $1359-1392$.

WANG, H., LAW, K. S., HACKETT, R. D., WANG, D., \& CHEN, Z. X. (2005). "Leadermember exchange as a mediator of the relationship between transformational leadership and followers' performance and organizational citizenship behavior". Academy of management Journal, 48(3): 420-432. 
WANG, Z., ZHANG, J., THOMAS, C.L., YU, J. and SPITZMUELLER, C. (2017), "Explaining benefits of employee proactive personality: the role of engagement, team proactivity composition and perceived organizational support", Journal of Vocational Behavior, 101: 90-103.

WONG, C. A., S LASCHINGER, H. K., \& CUMMINGS, G. G. (2010). "Authentic leadership and nurses' voice behaviour and perceptions of care quality". Journal of nursing management, 18(8): 889-900.

XIE, J., CHU, X., ZHANG, J. and HUANG, J. (2014), "Proactive personality and voice behavior: the influence of voice self-efficacy and delegation", Social Behavior and Personality, 42(7): 1191-1200. 